\title{
On the Greenspan Resonance of Meteotsunamis in the Yellow Sea - Insights from the Newly Discovered 2009 Event
}

\author{
Jihwan Kim ( $\nabla_{\text {jihwan.kim@ipma.pt ) }}$ \\ Instituto Portugues do Mar e da Atmosfera
}

\section{Byoung-Ju Choi}

Chonnam National University

\section{Rachid Omira}

Universidade de Lisboa Faculdade de Ciências: Universidade de Lisboa Faculdade de Ciencias

\section{Research Article}

Keywords: 2009 meteotsunami, Yellow Sea, spectral analysis, numerical modeling, Greenspan resonance.

Posted Date: August 19th, 2021

DOI: https://doi.org/10.21203/rs.3.rs-804240/v1

License: (1) (i) This work is licensed under a Creative Commons Attribution 4.0 International License.

Read Full License 


\section{Abstract}

The Yellow Sea is recognized as a meteotsunami "hot-spot", with a relatively high rate of events' occurrence. The March 2007 and May 2008 meteotsunami events attracted large attention due to their deadly and high impact on the west coast of the Korean Peninsula. However, other small size meteotsunamis remain less known because of their insignificant coastal effect. Yet, a better understanding of meteotsunami hazard in the Yellow Sea requires thorough investigation of both large and small events. This paper reveals the occurrence of a meteotsunami on 11-12 June 2009 in the eastern Yellow Sea. It addresses the analyses of both the recorded sea-level and air-pressure data, the correlation between the atmospheric forcing and the meteotsunami formation, the numerical modeling of meteotsunami propagation, and the resonance effects on the recorded waves. Analysis results evidence a moving air-pressure jump of about $3 \mathrm{hPa}$ that disturbed the sea surface and caused a meteotsunami with wave height up to $0.45 \mathrm{~m}$ (crest-to-trough). Both meteorological observations and numerical modeling suggest a speed of 11 to $13 \mathrm{~m} / \mathrm{s}$ for the atmospheric disturbance propagation, which is much smaller than the optimal condition for Proudman resonance of meteotsunamis in the eastern Yellow Sea. Here, we demonstrate that the Greenspan resonance was responsible for amplifying the incident waves. Despite the insignificant coastal impact of the 11 June 2009 event, its investigation unravels new insights into the formation, amplification, and hazard extent of small size meteotsunamis in the Yellow Sea.

\section{Introduction}

Meteorological tsunamis (or meteotsunamis) are high-energy ocean waves in the frequency band of ordinary tsunamis (Monserrat et al. 2006). They occur under specific atmospheric conditions: typically a moving air-pressure disturbance associated with thunderstorms, gravity waves, squall lines, convective systems, or frontal passages (Pattiaratchi and Wijeratne 2015). Although meteotsunamis exhibit similarity to tsunamis in the way they damage the coast, their consequences are often limited to specific bays, inlets and harbors. However, some events have evidenced the potential of meteotsunami to produce regional impact (Šepić et al. 2015).

Recent compilations of past events show that the meteotsunami is a global phenomenon (Rabinovich 2020; Gusiakov 2021)). While meteotsunamis are documented in almost all the oceans and seas of the globe, they are more frequent in regions favouring their formation and amplification. The Adriatic Sea, the Balearic Sea, the Great Lakes and southeast Asia and adjacent marginal seas are all examples of meteotsunami "hot-spots" with a high frequency of destructive events' occurrence.

Meteotsunamis are recognized as nontrapped long waves or trapped edge waves that undergo a multiresonant process while propagating towards the coastal areas (Bechle et al. 2015). Proudman resonance (Proudman 1929) amplifies the nontrapped long waves when the generating atmospheric disturbance travels with a speed approximately equal to the phase speed of long waves $\left(C_{l w}=\sqrt{g h}\right.$, where $g$ is the gravitational acceleration and $h$ is the water depth). Trapped edge waves are amplified under the 
Greenspan propagation resonance (Greenspan 1956) when the atmospheric disturbance moves with a speed close to the speed of propagation of one of the modes of the edge wave (

$C_{\text {edge }}=g / \sigma[\tan (2 n+1) \beta]$, where $\sigma$ is the edge wave frequency, $\mathrm{n}$ is the mode number and $\beta$ is the bottom topographic slope). Although Proudman resonance is commonly responsible for amplifying most of the documented meteotsunami waves (Rabinovich 2020), Vilibić and Šepić (2009), and Bechle and Wu (2014) showed through numerical modelling that Greenspan resonance was responsible for the meteotsunamis in the the Adriatic and the Great Lakes, respectively.

In the Yellow Sea, meteotsunamis are quite frequent (Choi et al. 2014; Kim et al. 2016; Kim et al. 2017; Rabinovich 2020). The March 2007 and May 2008 meteotsunamis are the well-known and studied events because of their deadly and high impact on the Korean Peninsula coasts. The 30th and 31st March 2007 event resulted in about $1.5 \mathrm{~m}$ wave heights that killed three people, injured two others, and caused damage to more than 100 fishing boats along the west coast of Korea (Choi et al. 2014). The 3rd and 4th May 2008 was the deadliest meteotsunami in the recorded history of the Yellow Sea, with 9 people killed and 15 injured after being swept out by unexpected waves along the Korean coast (Kim et al. 2017). Choi et al. (2014) demonstrated that the Proudman resonance was responsible for amplifying the March 2007 meteotsunami waves and emphasized the importance of meteotsunami-tide interaction. Kim et al. (2016) reported a moving air-pressure jump of $1.8 \mathrm{hPa}$ as the cause of the May 2008 meteotsunami with recorded waves in the range of $0.2 \mathrm{~m}$, which leaves unexplained the high death toll from this event. Despite the great effort on studying the 2007 and 2008 events, extensive work remains to better understand the generation mechanism and wave amplification of meteotsunamis in the Yellow Sea. This requires, in our view, thorough investigation of less known events in the Yellow Sea, allowing to unravel new insights into the generation mechanisms and amplification of meteotsunami waves in the region.

This paper reveals the occurrence of a meteotsunami event on 11th and 12th June 2009, in the Yellow Sea. It uses the analysis of both recorded sea-level and atmospheric data to characterize the observed tsunami-like waves and their origin. Numerical modelling is then employed to reproduce the observed waves and suggest the atmospheric conditions responsible for their formation. Interestingly, the newly discovered June 2009 meteotsunami shows resonance conditions different from those often occurred for the studied events in the Yellow Sea (i.e., the March 2007 meteotsunami).

\section{Tsunami-like Waves In The Yellow Sea In June 2009}

On June 11th and 12th, 2009, the tide gauge network in the Yellow Sea (Fig. 1) recorded uncommon sea surface disturbances with long wavelengths. These tsunami-like waves were observed on the west coast of Korea, raising the question of their origin. We excluded possible tectonic sources since no tsunamigenic earthquake was reported to take place in the region at the time the waves were observed. Because of the frequent occurrence of meteotsunamis in the region, we focus on searching for the meteorological conditions leading to the formation of the tsunami-like event. We find that the atmospheric observatories located along the Korean coast (Fig. 1) recorded a moving air-pressure jump, which supports the meteorological origin of the observed long ocean waves. 


\subsection{Long wave observations at tidal gauges}

We collected the 1-minute sea-level data from Korea Hydrographic and Oceanographic Agency (KHOA) and Korea Meteorological Administration (KMA). We analysed the anomalies along the west coast of Korea between 11th and 12th June, 2009, and observed that 10 different tidal gauges (see Fig. 1 and Table 1 for location) recorded a long wave event. Figure 2a depicts the sea-level signals observed at the 10 coastal sensors, where the time is local standard time (UTC +9$)$. The de-tiding of these records ( 3 hour high-pass filter) enables isolating the sea-level disturbances that occurred on the 11th and 12th June, 2009 (Fig. 2b). We find that the recorded waves have maximum peak-to-trough heights from $14 \mathrm{~cm}$ to 45 $\mathrm{cm}$. The wavelet spectrum analysis (Fig. 2c) shows periods of the waves between 30 minutes and 2 hours, which are in the period range of tsunami waves. The arrival times of the long waves at the coastal stations (Fig. 2b) allow inferring that the phenomenon started from the north and propagated to the south. Table 2 summarizes the event characteristics at each gauge station, including the onset time, the maximum elevation height and the time of the maximum wave occurrence.

Table 1

List of observatories

\begin{tabular}{|llllll|}
\hline Observatory & Latitude & Longitude & Source & Atm. pressure & Tide gauge \\
\hline KRB & 36.62544 & 125.55954 & KMA & 0 & \\
\hline OYD & 36.22920 & 126.07583 & KMA & 0 & \\
\hline MD & 35.85799 & 126.31507 & KMA & 0 & \\
\hline SYD & 35.80880 & 126.39770 & KMA & 0 & \\
\hline AH & 36.67361 & 126.13222 & KHOA & 0 & 0 \\
\hline ECD & 36.11722 & 125.98472 & KHOA & 0 & 0 \\
\hline JH & 36.00694 & 126.68750 & KHOA & 0 & 0 \\
\hline KS & 35.97556 & 126.56306 & KHOA & 0 & 0 \\
\hline IC & 37.45194 & 126.59222 & KHOA & 0 & 0 \\
\hline AS & 37.19222 & 126.64722 & KHOA & 0 & 0 \\
\hline DS & 37.00750 & 126.35278 & KHOA & 0 & 0 \\
\hline BR & 36.40639 & 126.48611 & KHOA & & 0 \\
\hline YG & 35.42611 & 126.42056 & KHOA & 0 & 0 \\
\hline HSD & 34.68417 & 125.43556 & KHOA & 0 & \\
\hline
\end{tabular}


Table 2

Meteotsunami starting time, maximum amplitude with its arrival time and maximum peak-to-trough height. (* indicates 11 June. Other times are on 12 June.)

\begin{tabular}{|lllll|}
\hline Location & $\begin{array}{l}\text { Meteotsunami } \\
\text { starting time }\end{array}$ & $\begin{array}{l}\text { Maximum surface } \\
\text { elevation }(\mathbf{c m})\end{array}$ & $\begin{array}{l}\text { Maximum } \\
\text { elevation time }\end{array}$ & $\begin{array}{l}\text { Maximum peak-to- } \\
\text { trough height (cm) }\end{array}$ \\
\hline IC (Incheon) & $\star 21: 50$ & 5.79 & $3: 05$ & 14.22 \\
\hline AS (Ansan) & $\star 23: 25$ & 10.63 & $2: 24$ & 29.13 \\
\hline DS (Daesan) & $\star 21: 20$ & 11.06 & $0: 07$ & 21.34 \\
\hline AH (Anheung) & $\star 21: 50$ & 10.83 & $0: 07$ & 19.43 \\
\hline BR (Boryung) & $\star 23: 35$ & 7.14 & $2: 35$ & 16.13 \\
\hline $\begin{array}{l}\text { ECD } \\
\text { (Eocheong- }\end{array}$ & $* 23: 25$ & 10.45 & $0: 11$ & 23.19 \\
\hline $\begin{array}{l}\text { JH }) \\
\text { (Janghang) }\end{array}$ & $* 23: 35$ & 22.67 & $1: 39$ & 44.92 \\
\hline KS (Kunsan) & $* 22: 25$ & 15.73 & $1: 14$ & 25.47 \\
\hline $\begin{array}{l}\text { YG } \\
\text { (Younggwang) }\end{array}$ & $* 23: 55$ & 17.45 & $1: 34$ & 38.53 \\
\hline $\begin{array}{l}\text { HSD } \\
\text { (Heuksan-Do) }\end{array}$ & $* 23: 45$ & 15.25 & $0: 44$ & 30.95 \\
\hline
\end{tabular}

\subsection{Meteorological origin of the tsunami-like event 2.2.1. Atmospheric Pressure Jump}

The search for the origin of the tsunami-like waves led us to collect and analyse atmospheric data for the period between 11th and 12th June, 2009. High-resolution (1-minute) air-pressure data were obtained at 8 different observatories from KHOA and KMA (Fig. 1 for location). Figure 3 shows the original air-pressure records (Fig. 3a), the filtered signals (Fig. 3b) and their wavelet spectrum analysis (Fig. 3c). We notice that all the observatories recorded a moving air-pressure jump of about $3 \mathrm{hPa}$ (Figs. $3 a$ and $3 \mathrm{~b}$, and Table 3 ). The arrival times of the atmospheric disturbance to the observatories (Fig. 3b) suggest a propagation from north to south, which is in agreement with the propagation direction of the observed long ocean waves (Fig. 2b). Moreover, the atmospheric pressure has maintained similar magnitudes (Fig. 3b) and periods (Fig. 3c) while propagating from north to south. 
Table 3

Maximum atmospheric pressure change, elapsed time for the change, and the observed time at airpressure observatories. Asterisk (*) indicates time on 11 June. Other times are on 12 June.

\begin{tabular}{|lll|}
\hline Location & Largest pressure change / elapsed time & Time of maximum pressure jump (hr:min) \\
\hline $\mathrm{KRB}$ & $2.80 \mathrm{hPa} / 10 \mathrm{~min}$. & $\star 23: 12$ \\
\hline $\mathrm{AH}$ & $2.82 \mathrm{hPa} / 17 \mathrm{~min}$. & $\star 23: 24$ \\
\hline $\mathrm{OYD}$ & $2.55 \mathrm{hPa} / 12 \mathrm{~min}$. & $00: 12$ \\
\hline $\mathrm{ECD}$ & $2.36 \mathrm{hPa} / 19 \mathrm{~min}$. & $00: 35$ \\
\hline $\mathrm{JH}$ & $2.86 \mathrm{hPa} / 17 \mathrm{~min}$. & $01: 02$ \\
\hline $\mathrm{KS}$ & $2.40 \mathrm{hPa} / 15 \mathrm{~min}$. & $01: 03$ \\
\hline $\mathrm{MD}$ & $3.24 \mathrm{hPa} / 18 \mathrm{~min}$. & $01: 14$ \\
\hline $\mathrm{SYD}$ & $2.48 \mathrm{hPa} / 15 \mathrm{~min}$. & $01: 19$ \\
\hline
\end{tabular}

Analysis of the filtered air-pressure records at coastal stations equipped with both tide gauge and atmospheric sensors (i.e., AH, ECD, JH and KS observatories, see Fig. 1 for location) indicates that the tsunami-like waves started arriving at the sea-level stations approximately two hour after the passage of the atmospheric disturbances (Fig. 4). This observation suggests that the air-pressure jump was responsible for the offshore onset of the tsunami-like event that while propagating towards the coast its interaction with the sea floor topography results in delayed arrival time and possible amplification of the waves.

\subsubsection{Wind speed, direction and temperature}

We investigated the changes in the surface wind speed, direction and atmospheric temperature as key indicators of the atmospheric disturbance passage over the coastal area of the Yellow Sea. The surface wind speeds and directions before and after the passage of the atmospheric pressure jump are compared in Fig. 5. Before the atmospheric pressure jump reached the region, the surface wind direction was from south to north. As soon as the pressure jump passed by (approximately 20 minutes later), the surface wind direction changed to the opposite direction, i.e., from northwest to southeast. Contour lines in Fig. 5 present the travel times of both the lowest (left panel) and the highest (right panel) atmospheric pressure anomalies passed through. The contours are plotted perpendicular to the propagation direction of the airpressure with an interval of $10 \mathrm{~min}$. We observe that the highest and lowest pressure anomalies propagate with almost the same speed and direction.

As the pressure disturbance moves over this area, atmospheric data also show a drastic change in the temperature. The latter dropped by $2.2,2.6$ and $3.0^{\circ} \mathrm{C}$ at AH, ECD and KS observatories, respectively. This temperature drop occurred within 20 min which coincides with the passage of the air-pressure jump. 
Therefore, the changes of wind direction, speed and temperature support the southward passage of a cold front through this area.

\section{The June 2009 Meteotsunami Dynamics}

\subsection{Estimation of air-pressure jump speed and direction}

Analysis of the observed air-pressure signals demonstrated that the pressure jump propagated southward with a constant speed and direction while maintaining a similar magnitude (see Sect. 2.2). Here, we quantitatively infer the speed and direction of the pressure jump propagation based on the meteorological observation. Figure 6 shows the radar images (from KMA) of the rain rate at 23:00, 23:20, 23:40 and 24:00 of June 11th. These observations relate the pressure jump with the first rain precipitation, which is marked as a dashed line in Fig. 6 . We can observe that a strong rain precipitation followed after the pressure jump, but this rain activity seems not to be directly linked to the pressure jump.

To estimate the speed and direction, we introduce some assumptions and perform numerical tests based on the air-pressure data. For the sake of simplicity, we assume that the pressure jump is aligned in a straight line and the moving direction is perpendicular to the alignment. Moreover, we assume that the speed and direction of pressure jump are constant, as demonstrated in Sect. 2.2. With these assumptions, the pressure jump directional angle, defined as the counter-clockwise angle with $0^{\circ}$ toward east (see Fig. 1), is estimated between $275^{\circ}$ and $295^{\circ}$ based on the radar images of Fig. 6 . On the other hand, the estimation of the propagation speed of pressure jump from radar images (Fig. 6) was not possible because of the low resolution and the uncertainty on the exact location of the jump in these images. To overcome this limitation, numerical tests allowing a more precise determination of the speed and direction are performed using the pressure records at KRB, ECD, MD and HSD observatories as input (see Fig. 1 for location). We interpolated the atmospheric pressure, and compared the observation at AH, OYD, $\mathrm{KS}$ and $\mathrm{JH}$ with the numerical simulations in Fig. 7. Based on these tests, we estimate the speed between $11 \mathrm{~m} / \mathrm{s}$ and $13 \mathrm{~m} / \mathrm{s}$ and the directional angle between $275^{\circ}$ and $285^{\circ}$.

\subsection{Resonance effects}

From the previous section, the atmospheric pressure records support that the moving direction of the pressure jump was in the range of $275^{\circ}$ and $285^{\circ}$ and the moving speed was in the range of $11 \mathrm{~m} / \mathrm{s}$ and $13 \mathrm{~m} / \mathrm{s}$. In the study area of the eastern Yellow Sea, the optimal moving speed of atmospheric disturbances leading to Proudman resonance and the occurrence of meteotsunami is estimated to 26-29 $\mathrm{m} / \mathrm{s}$ (Choi et al. 2014). Therefore, the meteotsunami long-waves recorded on 11-12 June 2009 could not be associated with the Proudman resonance as our estimated moving speed of air-pressure jump (11-13 $\mathrm{m} / \mathrm{s}$ ) is much smaller than the optimal condition for such a resonance. During the previously known meteotsunami events in this region, the moving direction of atmospheric disturbances was toward the coast. However, on June 11-12, 2009, the atmospheric disturbances moved along the coast, i.e.,the 
moving direction was smaller than $290^{\circ}$, which is a favorable condition for edge waves to propagate and to be amplified by Greenspan resonance.

In order to explain the meteotsunami amplification, we turn to the Greenspan resonance which can intensify the propagating edge waves along the coast. Greenspan resonance states the relation of wave frequency, wave mode and the sea bed slope as follows,

$$
C_{\text {edge }}=g \operatorname{Ttan}[(2 n+1) \beta] / 2 \pi
$$

When the speed of the atmospheric jump is close to the speed of one of the edge wave modes, the Greenspan resonance is expected. The sea bed from KRB to MD has a gentle slope ( $\beta$ ) of approximated 0.0008 (Choi et al. 2014), and the resonant wave period ( $T$ ) of 147-173 min corresponds to the speed $\left(C_{\text {edge }}\right) 11-13 \mathrm{~m} / \mathrm{s}$ of the fundamental mode $(n=0)$. Since both the trapped wave speed and the moving speed of air-pressure disturbance are in the same range, the condition for the Greenspan resonance is satisfied.

Furthermore, each period corresponds to the mode of the Greenspan resonance periods which are 160, 53 , and $32 \mathrm{~min}$ for $\mathrm{n}=0,1$ and 2, respectively, for the speed $12 \mathrm{~m} / \mathrm{s}$. Figure 8 shows the Fourier spectrum of sea-level anomaly data observed at $\mathrm{BR}, \mathrm{JH}, \mathrm{KS}$ and $\mathrm{YG}$ tide observation stations. The dominating periods, such as $144-120,72-48$, and 30 min, of the sea-level fluctuations (Figs. 2c and 8) are in good agreement with the analytically calculated periods of the Greenspan resonance.

\subsection{Numerical simulations of June 2009 meteotsunami}

The GeoClaw numerical code (LeVeque et al. 2011), a finite volume method solver of the nonlinear shallow water equations, is used to simulate the propagation of the tsunami-like waves in the Yellow Sea. To account for the air-pressure jump as a trigger and driver of meteotsunami propagation, the GeoClaw code was equipped with atmospheric pressure forcing terms following the governing equations presented in Kim and Omira (2021).

The atmospheric pressure records at KRB, ECD, MD and HSD observatories are used as the model's input to force the sea surface. In other coastal areas, with no available atmospheric data, these records were interpolated to estimate the air-pressure disturbances. Details on the interpolation process can be found in Kim and Omira (2021). The propagation of the meteotsunami waves is then simulated over a uniform bathymetric grid spacing of $\mathrm{dx}=\mathrm{dy}=20$ " ( $500 \mathrm{~m}$ ) (Fig. 1).

Numerical simulation results are presented for air-pressure disturbances propagating at a speed of 12 $\mathrm{m} / \mathrm{s}$ and with a directional angle of $280^{\circ}$, both selected over the estimated range of $11-13 \mathrm{~m} / \mathrm{s}$ and $275-$ $285^{\circ}$ (Sect. 3.1). Figure 9 depicts the snapshots of modelled water surface elevation and atmospheric pressure, and it is clear that the atmospheric disturbances (right panels in Fig. 9) travel southward, passing over Korean coastal areas of interest with almost unchangeable magnitude of the pressure jump. 
These results are in good agreement with the observed air-pressure signals at most Korean coast stations.

Numerical simulations show that the moving air-pressure disturbances guide the meteotsunami propagation, and waves reaching $0.2 \mathrm{~m}$ in height are estimated along the Korean coast. The results also allow observing the delayed arrival of the meteotsunami waves with respect to the atmospheric disturbances, as the propagation of the sea long-waves is highly affected by the shallower depths of the Yellow Sea bathymetry. As the waves reach near the continental shelf, edge waves are observed in Fig. 10 (d)-(g), and an effect of the nearshore seafloor topography concerns the alteration in the propagation direction of the incident meteotsunami waves.

The observed sea-level records at six tidal gauge stations are compared with numerical model results (Fig. 11). The numerical model results are in good agreement with the observation. Thus, this numerical simulation also has the capability to capture the Greenspan resonance in the eastern Yellow Sea.

At ECD, the observed and simulated water surface elevation is small because the island ECD is located far from the coastline of the Korean Peninsula (Fig. 1) and the resonance was not fully developed. Moreover, the tidal gauge is inside the harbor which is facing southward. Since the meteotsunami waves propagate from the northwest to southeast, the observed water surface elevation at ECD is relatively small for this event.

Sea-level observation stations at KS and $\mathrm{JH}$ face each other across a river estuary and the distance between the two gauges is relatively small $(11.73 \mathrm{~km})$. The sea-level oscillation results from numerical simulations fairly reproduce the observations at both tidal gauges. We notice that other large long-waves arrived three hours apart after the passage of the large jump in the atmospheric pressure over this area. The cause of the second and the third large waves, which are well reproduced in the numerical simulation, was partly explained by the Greenspan resonance, but it still needs to be explored in future study including the wave reflection by the nearby islands.

\section{Discussion}

\subsection{The June 2009 Meteotsunami}

The 2009 meteotsunami studied here is an additional event demonstrating the frequent occurrence of hazardous meteotsunamis in the eastern Yellow Sea. The region was the place of deadly and destructive meteotsunamis in the recent past. The March 2007 and the May 2008 meteotsunamis are examples of these events that marked the recent memory of the Korean coastal community. They also brought to the fore the deadliest and destructive nature of meteotsunami occurring in the Yellow Sea, while they resulted from different magnitudes of atmospheric forcing that travelled under distinct conditions. The meteotsunami of 30-31 March 2007, was caused by a southward moving air-pressure jump of $\sim 4.0 \mathrm{hPa}$ leading to destructive and deadly $1.5 \mathrm{~m}$-height long-waves recorded on the west coast of Korea (Choi et al. 2014). Likewise, the 3-4 May 2008 meteotsunami was deadly on the west coast of Korea despite its 
relatively weak atmospheric forcing, $\sim 2.0 \mathrm{hPa}$ air-pressure jump, that propagated to the northeast (Kim et al. 2019).

The 2009 meteotsunami shares some similarities with past events in the region. The atmospheric forcing leading to the 2009 meteotsunami propagated southward as for the 2007 meteotsunami. However, records of air-pressure show jumps smaller than those in 2007 but larger than those led to the formation of the 2008 meteotsunami. Unlike both meteotsunamis of 2007 and 2008, there is no report of casualties or coastal damages associated with the 2009 meteotsunami waves. The arrival of the waves at low tide might have conditioned the hazard level of the 2009 meteotsunami, as the tidal stage in the Yellow Sea has a large influence on the amplification of the meteotsunamis in the region (Choi et al., 2014). Despite the insignificant coastal impact of the 2009 event, its study helps understand the hazard posed by small meteotsunamis in the Yellow Sea.

The analysis of sea-level and air-pressure data, both available with high temporal resolution, allows building a robust numerical model for the 2009 meteotsunami, based on a nonlinear shallow water code equipped with atmospheric forcing terms (Kim and Omira, 2021). Although propagation metrics of the meteotsunami-driven atmospheric instability are uncertain, the conducted numerical tests enable estimating the speed and direction of the observed air-pressure jumps to $12 \mathrm{~m} / \mathrm{s}$ and $280^{\circ}$, respectively. These values led to the best numerical reproduction of the recorded ocean waves. Overall, the simulated sea-level elevations show satisfactory agreement when compared to the observation records, particularly for the maximum wave height. At both $\mathrm{KS}$ and $\mathrm{JH}$, the numerical solution fits quite well the whole recorded waveform. At some other locations, we noticed some underestimation of the wave height by the numerical simulation (i.e. at ECD station) or misfit in the arrival time of the first wave (i.e. at DS and YG tide observation stations). We believe that these mismatches can be associated with the use of a coarse grid bathymetric model to perform the meteotsunami propagation simulations. Refined grids at coastal locations of the tide gauges could help improve the obtained numerical results.

\subsection{Resonance of meteotsunamis in the eastern Yellow Sea}

Previous studies on meteotsunamis in the eastern Yellow Sea have demonstrated that Proudman resonance is the main source of wave amplification (Choi et al., 2008; Choi et al., 2014; Kim et al., 2016; Kim et al., 2019). Choi et al. (2014) performed numerical simulations with atmospheric pressure jump speeds between $24 \mathrm{~m} / \mathrm{s}$ and $31 \mathrm{~m} / \mathrm{s}$, and showed that the optimal moving speeds for the Proudman resonance ranges from 26 to $29 \mathrm{~m} / \mathrm{s}$. Kim et al. (2019) examined three meteotsunamis recorded on the Korean coast in March 2007, May 2008 and April 2011, showing their association with atmospheric distrubances traveling with average speeds favoring the Proudman resonance. Our current study, on the other hand, demonstrates that relatively low average propagation speed of atmospheric disturbances ( $12 \mathrm{~m} / \mathrm{s}$ ) also leads to amplify meteotsunami waves under the Greenspan resonance. This fact suggests that Greenspan resonance should also be considered as an amplification mechanism of long waves in response to air-pressure disturbances moving along the coast in the Yellow Sea. Therefore, the range of the moving speed and direction of air-pressure disturbances leading to meteotsunami amplification 
needs to be widened. To provide insights on this, we performed and examined numerical simulations considering a wider range of speeds and directions.

Figure 12 shows the maximum water surface elevation of numerical simulations with incident angles varying from 275 to $340^{\circ}$, and a speed varying from 10 to $35 \mathrm{~m} / \mathrm{s}$ assuming that the atmospheric pressure observed at KRB moved at constant speed and angle. High sea-level elevation is observed when the moving speed of air-pressure disturbances is between 26 and $29 \mathrm{~m} / \mathrm{s}$ which supports the previous study by Choi et. al. (2014). We notice that long waves whose wave amplitudes are larger than $0.3 \mathrm{~m}$ can be generated even with relatively low moving speed $(12-18 \mathrm{~m} / \mathrm{s})$, and this speed range is in a condition for the Greenspan resonance as demonstrated in this study. In addition, to induce Greenspan resonance in the eastern Yellow Sea, the moving direction of atmospheric disturbances needs to be smaller than $290^{\circ}$,i.e., along the coast.

The importance of the wave amplification by Greenspan resonance is in the period of waves. We observed that the second wave arrived three hours after the first wave at $\mathrm{JH}$ and KS, and the amplitude of the second wave was as high as the first one (Fig. 2). The second wave was rather unexpected since it was observed three hours after the passage of the air-pressure jump.

\section{Conclusions}

This article is the first investigation of meteotsunamis associated with Greenspan resonance in the eatern Yellow Sea. It analyzes a newly discovered event (i.e. the June 2009) and demonstrates the importance of Greenspan resonance in amplifying meteotsunami waves in a sea region where Proudman resonance is considered as the main amplification factor (Choi et al. 2014, Kim et al. 2017). Proudman resonance in the estern Yellow Sea occurs when a pressure jump ( $>2 \mathrm{hPa}$ ) moves with a speed of $26-29 \mathrm{~m} / \mathrm{s}$ toward the west coast of Korea, leading often to damaging meteotsunamis on the harbor areas (Kim et al. 2017). Through the 11th and 12th June, 2009 case-study, this article reveals that even relatively slow moving atmospheric disturbances (i.e. speed 11-13 m/s) can invoke the Greenspan resonance, causing hazardous meteotsunamis in the region. One of the possible specifications of these events is the very long period of their waves, $2-3$ hours in some areas as obtained for the 2009 event.

Despite the insignificant impact of the 2009 event on the eastern Korean coast, its study helps acquire a better understanding on the meteotsunami generation and amplification mechanisms in the Yellow Sea "hot-spot" region. However, developing robust forecast meteotsunami capabilities in the region requires further studies. One is to study the harbor and bay resonance by analyzing the long-term tide observations due to the local bathymetry. Another is to investigate the reflection and focusing of the incoming wave rays by the bathymetry and coastline which are long and highly indented accompanied with many islands.

\section{Declarations}




\section{Conflict of interest}

The authors have no conflicts of interest to declare that are relevant to the content of this article.

\section{Acknowledgement}

This work is supported by the project FAST - Development of new forecast skills for meteotsunamis on the Iberian shelf - ref. PTDC/CTA-MET/32004/2017- funded by the Fundação para a Ciência e Tecnologia (FCT), Portugal. The authors would like to thank the Korea Hydrographic and Oceanographic Agency (KHOA) and Korea Meteorological Administration (KMA), for making both sea-level and airpressure data available. R. Omira acknowledges his CEECIND/04876/2017 research contact funded by FCT. The author would also like to acknowledge the financial support of FCT through project UIDB/50019/2020 - IDL.

\section{References}

1. Bechle AJ, Kristovich DAR, Wu CH (2015) Meteotsunami occurrences and causes in Lake Michigan, J. Geophys. Res. Oceans, 120, 8422-8438. https://doi.org/10.1002/ 2015JC011317.

2. Bechle A, Wu C (2014) The Lake Michigan meteotsunamis of 1954 revisited. Nat. Hazards 74, 155178. https://doi.org/10.1007/s11069-014-1193-5.Choi BJ, Park YW, Kwon KM (2008) Generation and growth of long ocean waves along the west coast of Korea in March 2007. Ocean and Polar Research, 30(4), 453-466. https://doi.org/10.4217/OPR.2008.30.4.453.

3. Choi BJ, Hwang C, Lee SH (2014). Meteotsunami-tide interactions and high-frequency sea level oscillations in the eastern Yellow Sea. Journal of Geophysical Research-Oceans, 119, 6725-6742. https://doi.org/10.1002/2013JC009788.

4. Greenspan M (1956) Propagation of sound in five monatomic gases. The Journal of the Acoustical Society of America, 28: 644-648. https://doi.org/10.1121/1.1908432.

5. Gusiakov VK (2021) Meteotsunamis at global scale: problems of event identification, parameterization and cataloguing. Nat Hazards 106, 1105-1123. https://doi.org/10.1007/s11069020-04230-2.

6. Kim J, Omira R (2021) The 6-7 July 2010 meteotsunami along the coast of Portugal: insights from data analysis and numerical modelling. Nat Hazards 106, 13971419. https://doi.org/10.1007/s11069-020-04335-8.

7. Kim MS, Kim H, Eom HM, Yoo SH, Woo SB (2019) Occurrence of hazardous meteotsunamis coupled with pressure disturbance traveling in the Yellow Sea, Korea. Journal of Coastal Research. 2019 Aug;91(SI):71-5.

8. Kim MS, Kim H, Kim YK, Yoo SH, Eom HM, Woo SB (2017). Determination of accurate arrival time of meteotsunami event in Yellow Sea. Journal of Coastal Research, 79, 149-153. 
9. Kim MS, Kim H, Kim YK, Gu BH, Lee HJ, Woo SB (2016). Double resonance effect at Daeheuksando Port caused by air pressure disturbances in Yellow Sea on 31 March 2007. Journal of Coastal Research, 75(sp1), 1142-1146. https://doi. org/10.2112/SI75-229.1.

10. LeVeque RJ, George DL, Berger MJ (2011) Tsunami modelling with adaptively refined finite volume methods. Acta Numerica, 20: 211-289. https://doi.org/10.1017/S0962492911000043.

11. Monserrat S, Vilibić I, Rabinovich AB (2006) Meteotsunamis: atmospherically induced destructive ocean waves in the tsunami frequency band, Nat. Hazards Earth Syst. Sci., 6, 10351051. https://doi.org/10.5194/nhess-6-1035-2006.

12. Pattiaratchi CB, Wijeratne EMS (2015) Are meteotsunamis an underrated hazard? Philos Trans R Soc A 373:20140377. https ://doi.org/10.1098/rsta.2014.0377.

13. Proudman J (1929) The Effects on the Sea of Changes in Atmospheric Pressure. Geophysical Journal International, 2: 197-209.

14. Rabinovich AB (2020) Twenty-Seven Years of Progress in the Science of Meteorological Tsunamis Following the 1992 Daytona Beach Event. Pure Appl. Geophys. 177, 1193-1230. https://doi.org/10.1007/s00024-019-02349-3

15. Šepić J, Vilibić I, Rabinovich AB, Monserrat S (2015) Widespread tsunami-like waves of 23-27 June in the Mediterranean and Black Seas generated by high-altitude atmospheric forcing. Scientific reports, 5(1), 1-8. https://doi.org/10.1038/srep11682.

16. Vilibić I, Šepić J (2009) Destructive meteotsunamis along the eastern Adriatic coast: overview. Phys. Chem. Earth 34, 904-917. https://doi.org/10.1016/j.pce.2009.08.004.

\section{Figures}


(a) Original signal
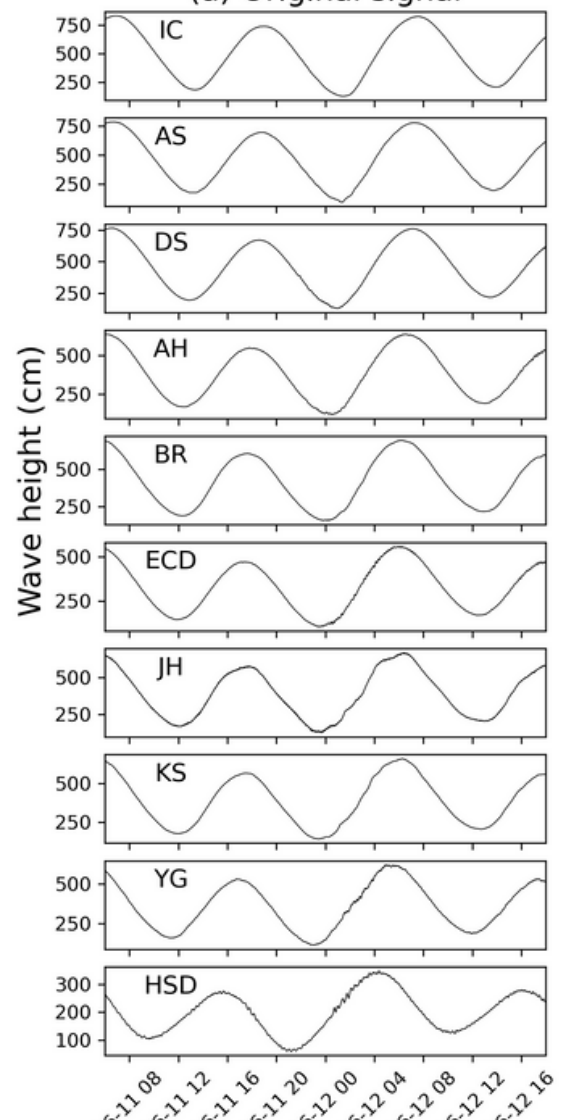

(b) Filtered signal
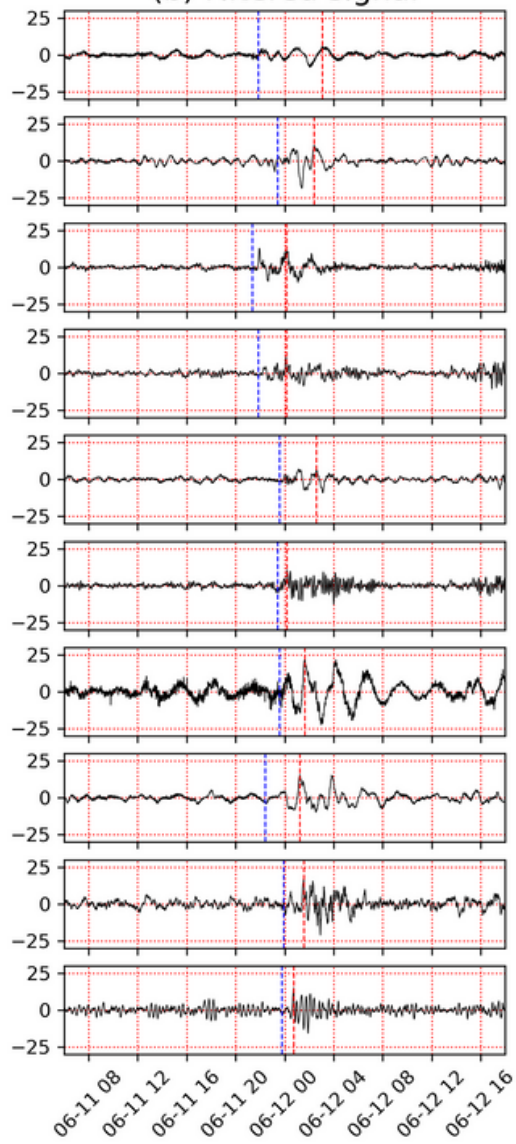

(c) Wavelet spectrum

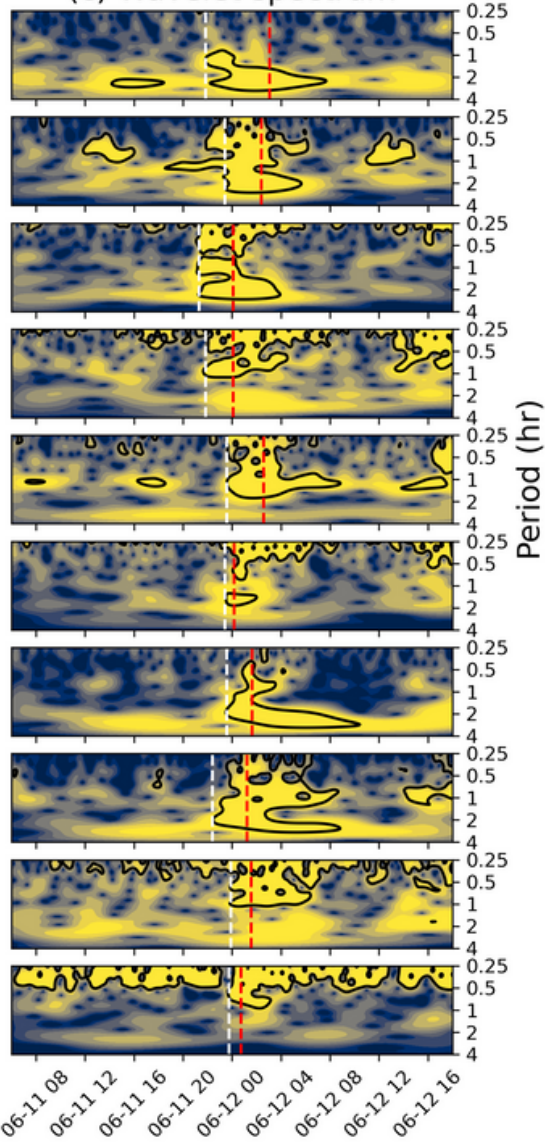

Figure 2

(a) Tidal gauge observations on 11-12 June 2009. (b) 3-hr high-pass filtered sea-level variations. Blue and red lines are the time of the initial meteotsunami event and of the maximum wave amplitude, respectively. (c) Spectral analysis with 95\% confidence (black contours) of periods between 10 minutes and 2 hours. White and red lines are the time of the initial meteotsunami event and of the time of maximum wave amplitude, respectively. 
(a) Original signal

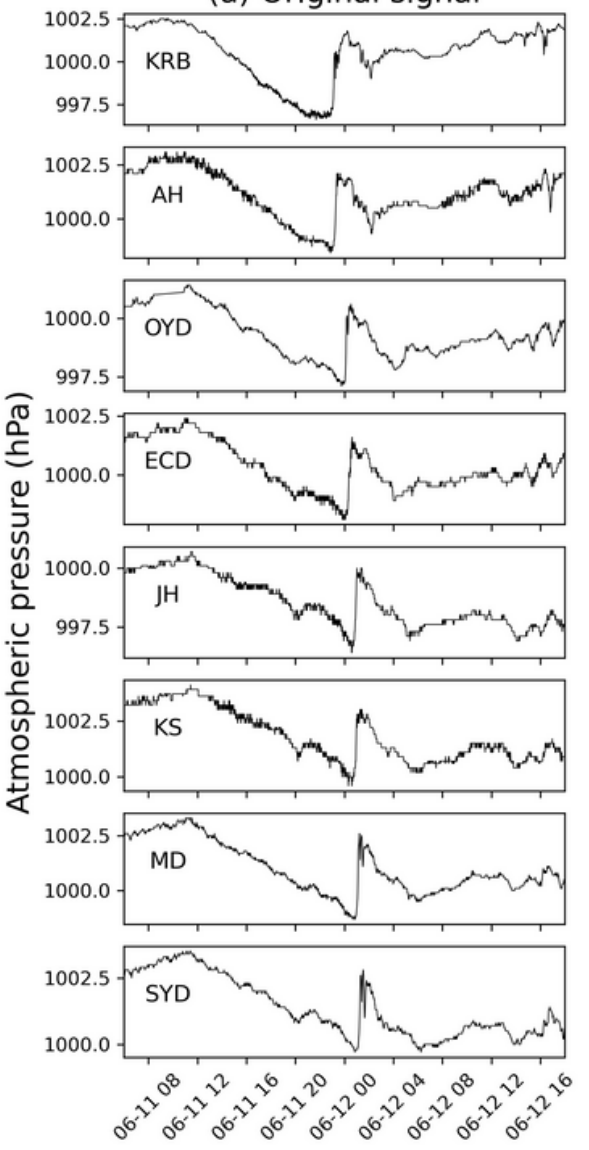

(b) Filtered signal
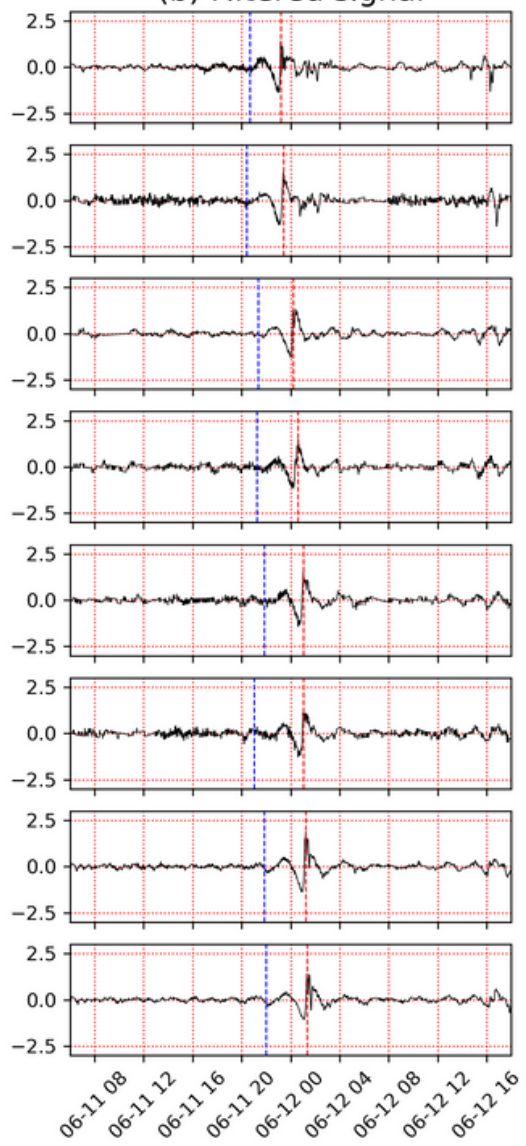

(c) Wavelet spectrum
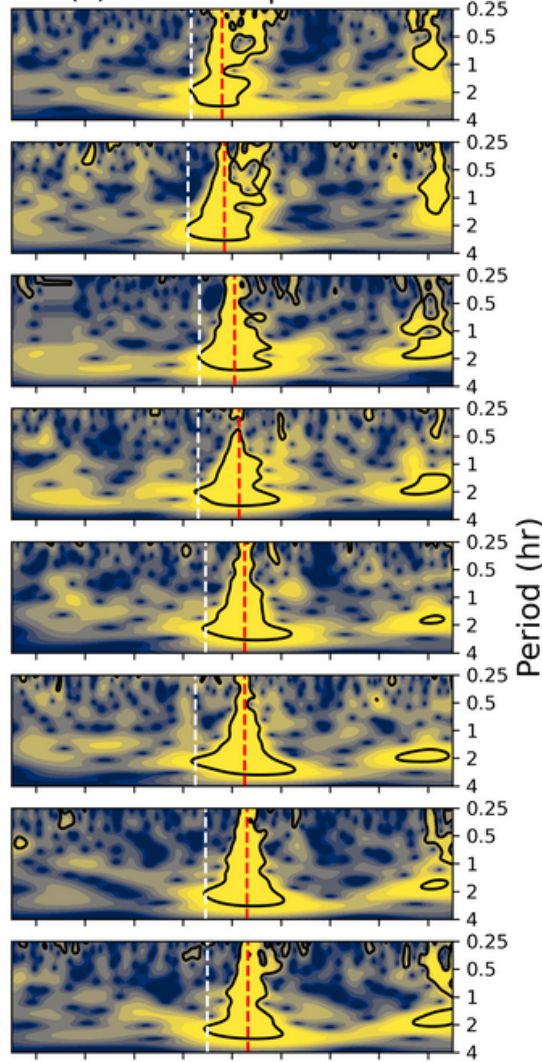

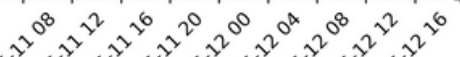
5

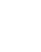

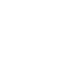

\section{Figure 3}

(a) Atmospheric pressure observation on 11-12 June 2009. (b) 3-hr high-pass filtered atmospheric pressure varations. Blue and red lines are the pressure perturbation starting time and maximum jump arrival time. (c) Spectral analysis with 95 percent confidence (black lines) of periods between 10 minutes and 2 hours. White and red lines are the pressure perturbation starting time and maximum jump arrival time. 


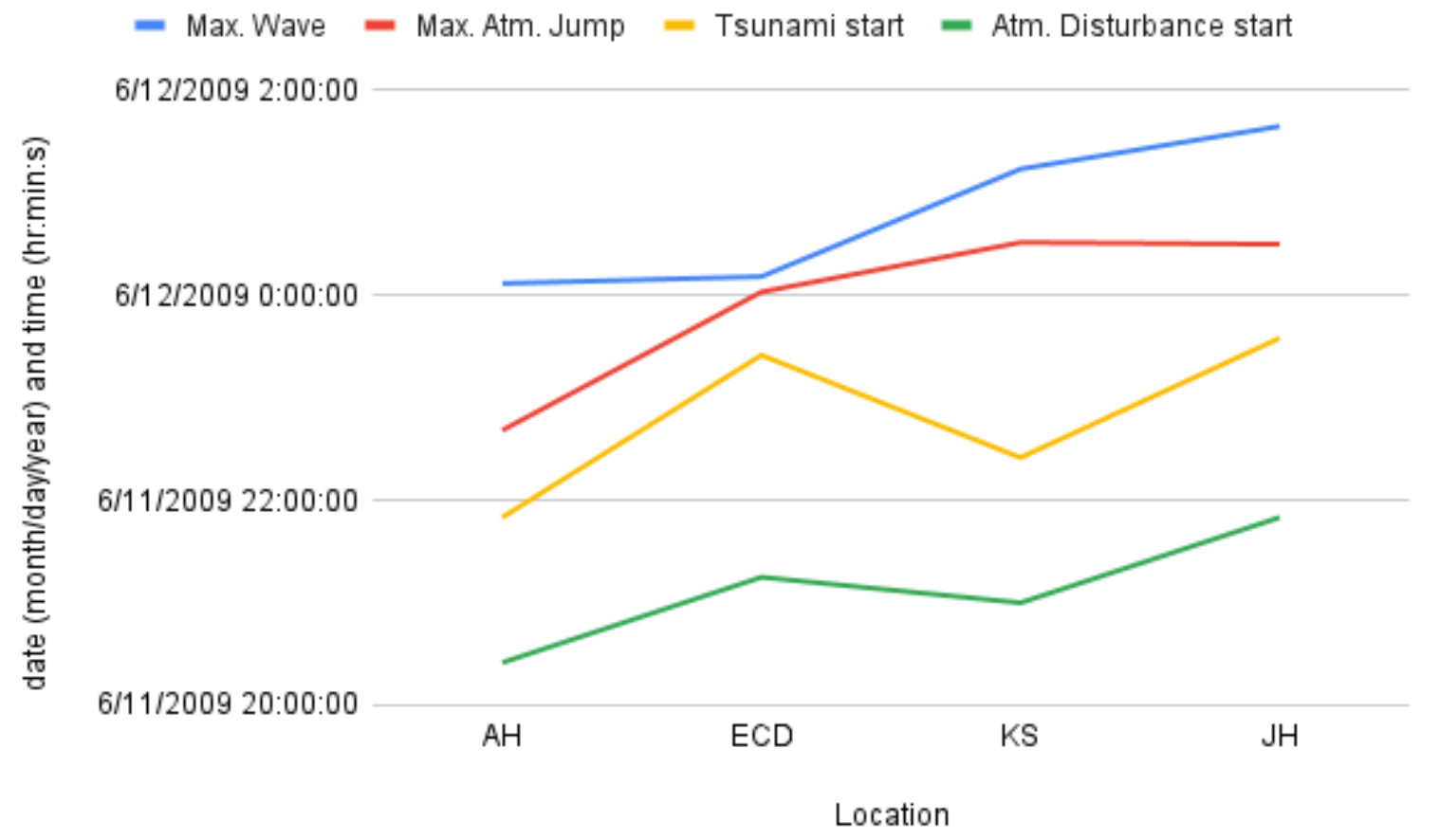

Figure 4

The starting times of tsunamis (yellow line) and atmospheric disturbances (green line), and arrival times of the maximum wave heights (blue line) and the maximum atmospheric pressure anomalies (red line) at the $\mathrm{AH}, \mathrm{ECD}, \mathrm{JH}$ and $\mathrm{KS}$ observatories.

(a) Before atm. jump

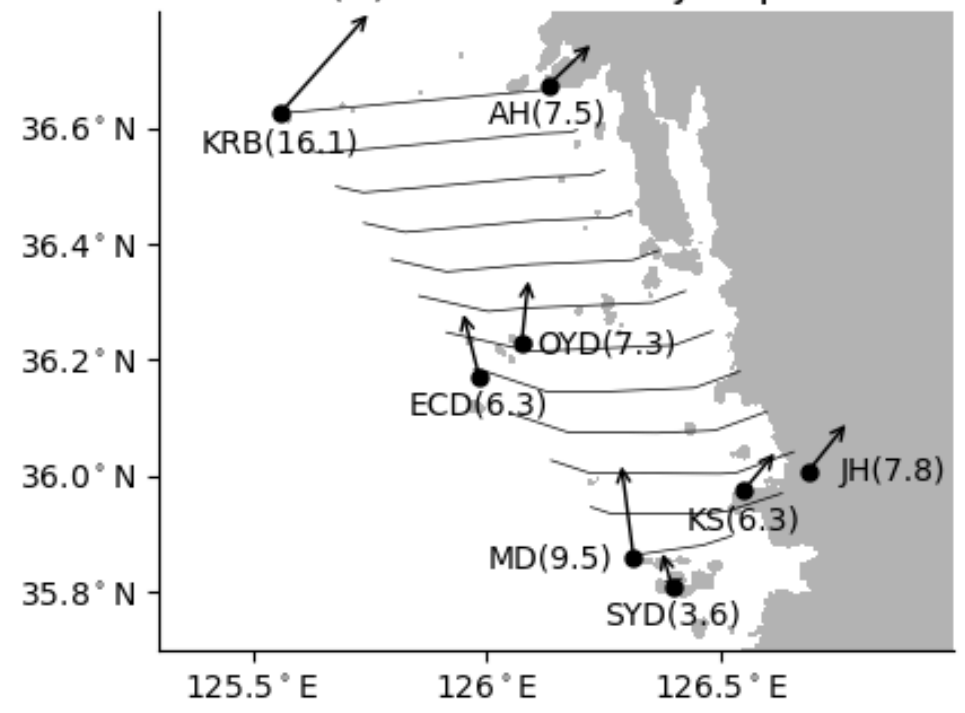

(b) After atm. jump

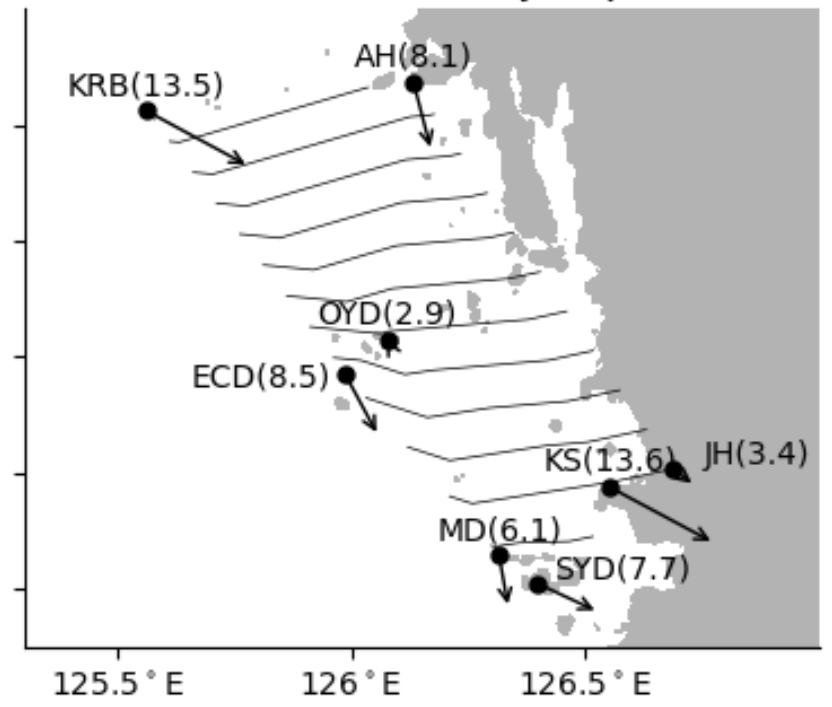

\section{Figure 5}

Wind speed and direction before (left) and after (right) the passage of atmospheric pressure jump. Arrows represent wind speed and direction, and the contour lines denote approximate locations of (left) lowest 
and (right) highest atmospheric pressure anomaly every 10 minutes. Numbers in parentheses are the wind speed in $\mathrm{m} / \mathrm{s}$.

(a) 2009-06-11 23:00

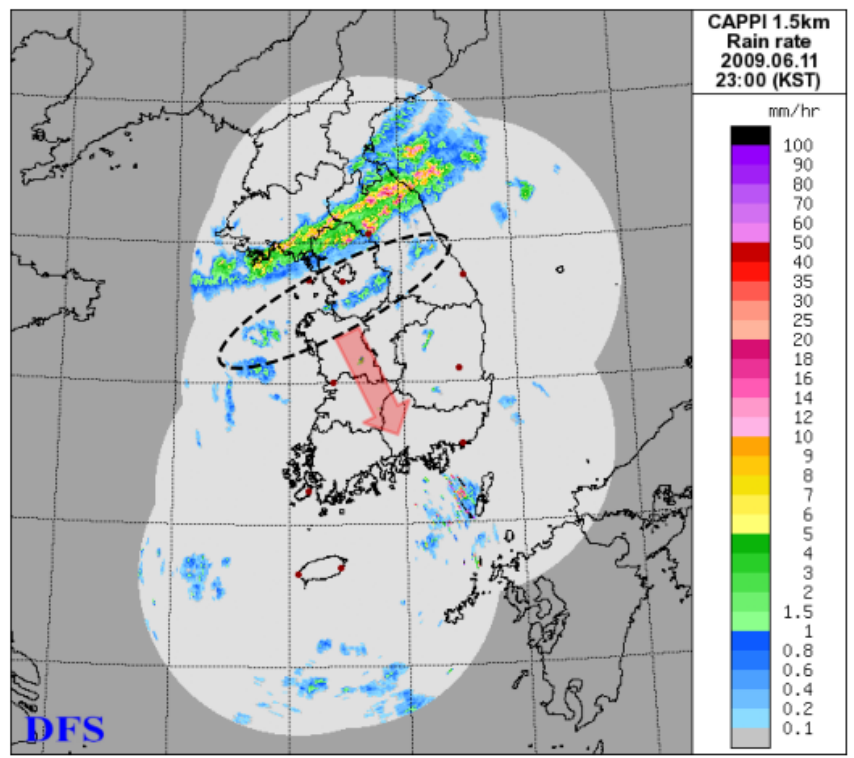

(c) 2009-06-12 00:00

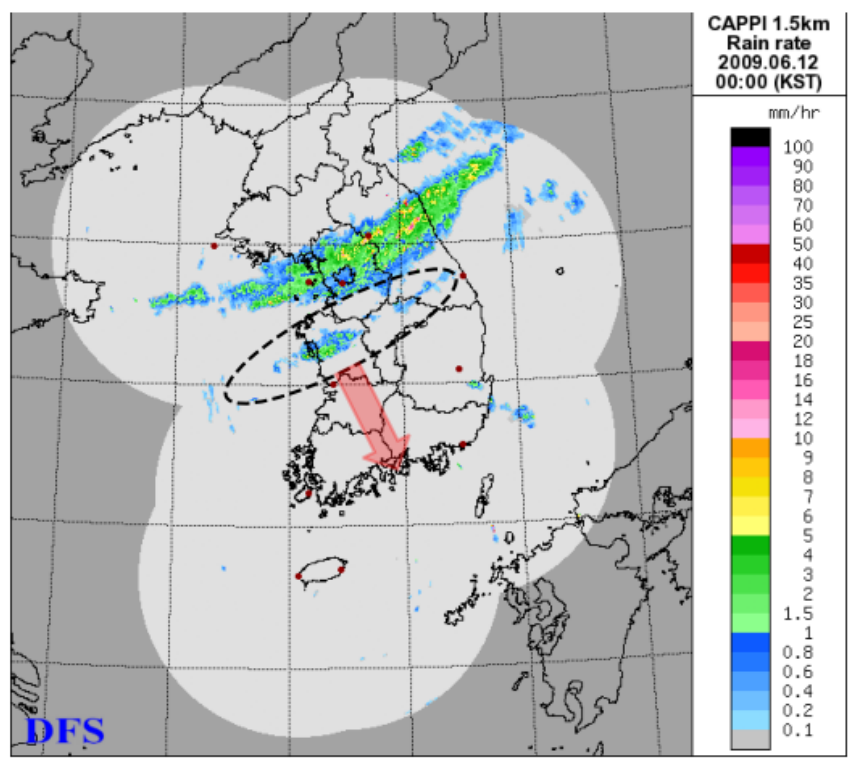

(b) 2009-06-11 23:30

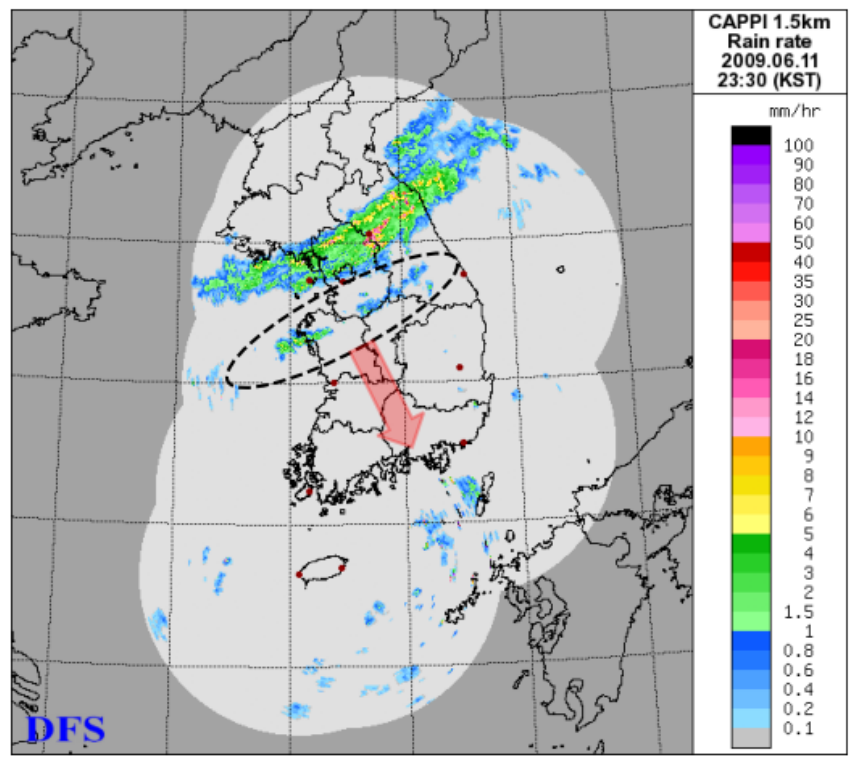

(d) 2009-06-12 00:30

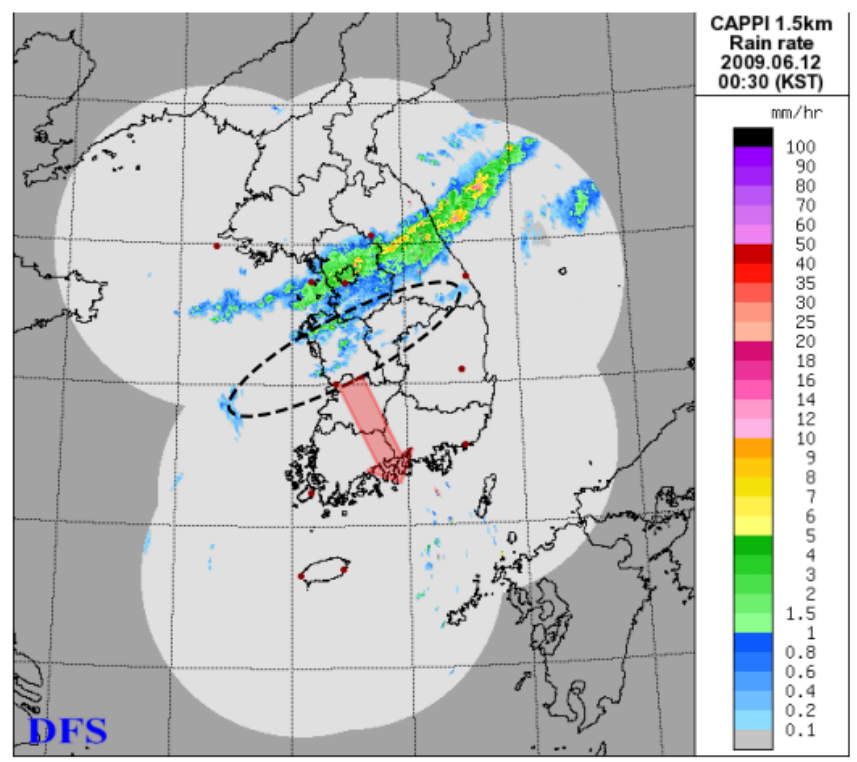

Figure 6

Radar images (from KMA) of the rain rate at 23:00, 23:30 (11 June), 00:00 and 00:30 (12 June). Black dashed ellipses mark the estimated location of the moving air-pressure jump. 

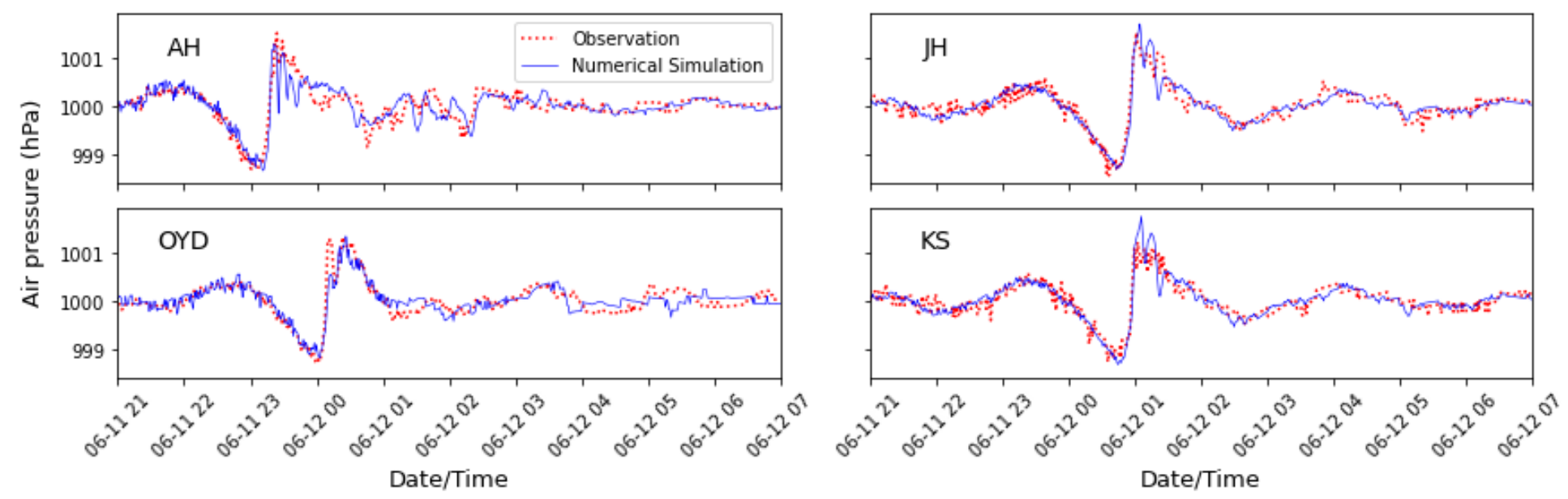

Figure 7

Comparison of filtered air-pressure from observation (red dotted line) and numerical simulation (blue line) with the moving direction $280^{\circ}$ and the speed $12 \mathrm{~m} / \mathrm{s}$.

(a) BR

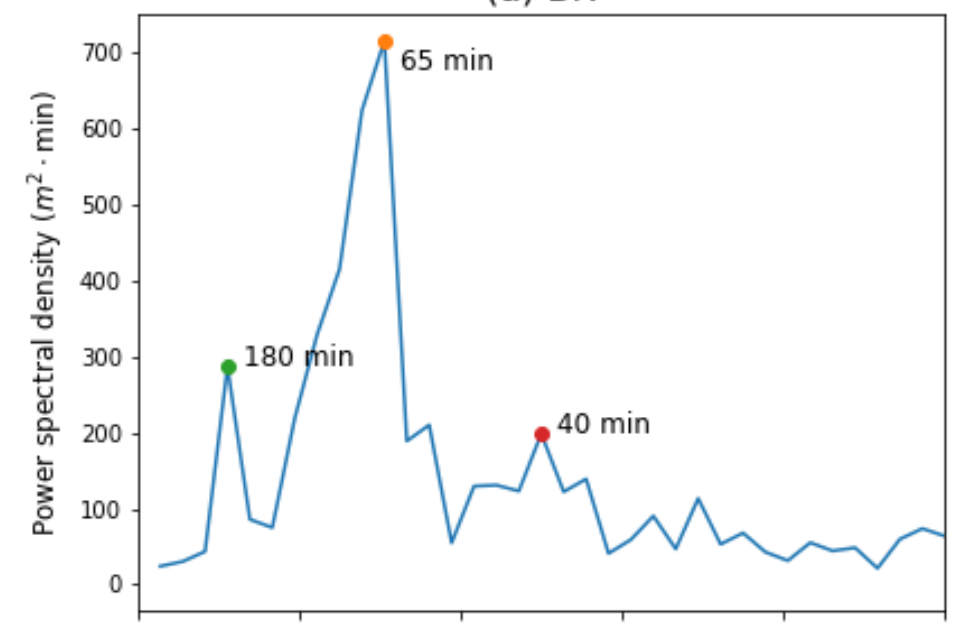

(c) $\mathrm{JH}$

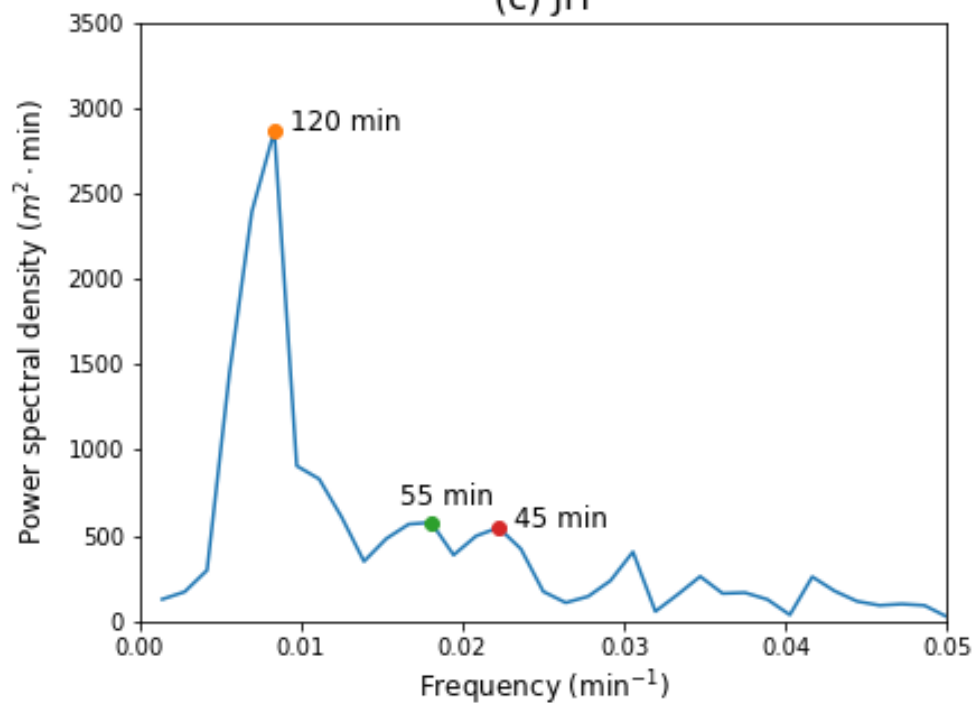

(b) KS

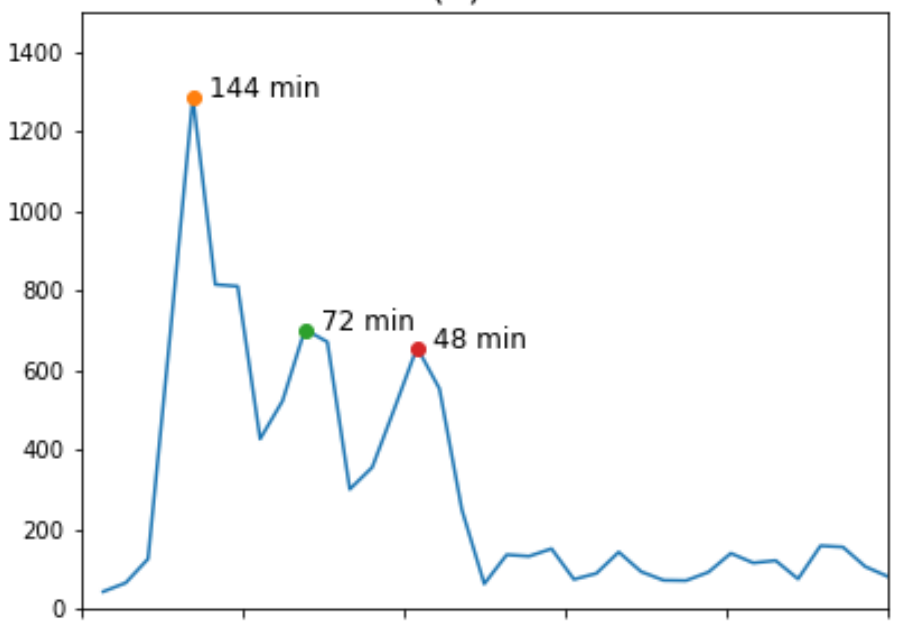

(d) YG

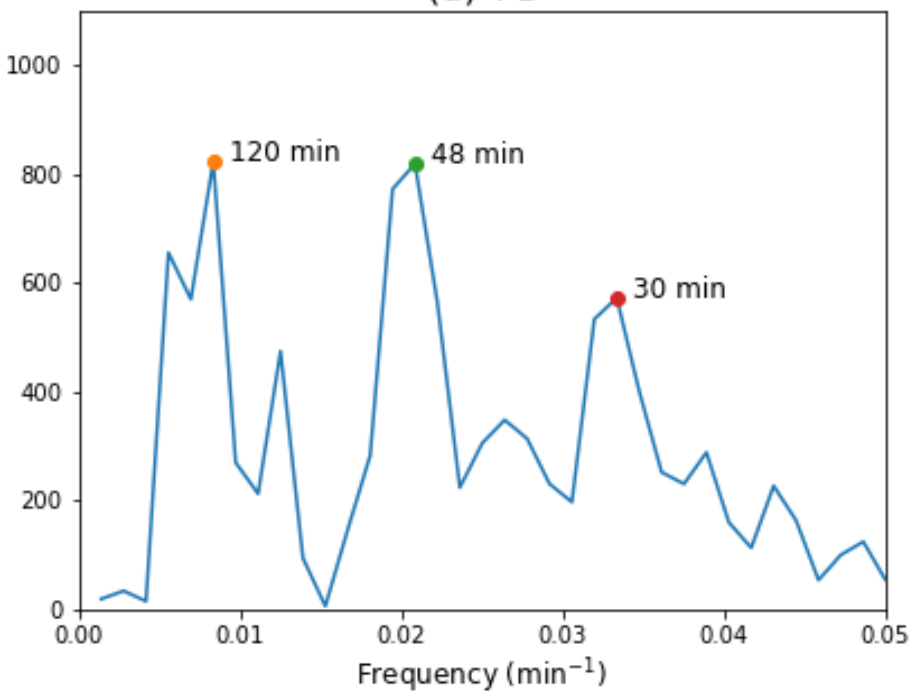

Figure 8 
Fourier spectrum of sea-level data from BR, KS, JH and YG tide observation stations between 11 and 12 June 2009.

(a) 2009-06-11 21:00

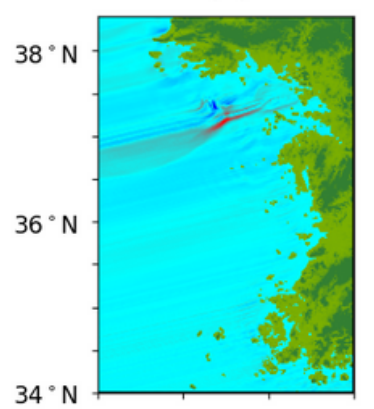

(d) 2009-06-12 00:00

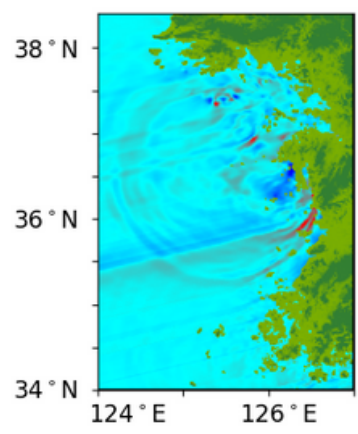

(b) 2009-06-11 22:00
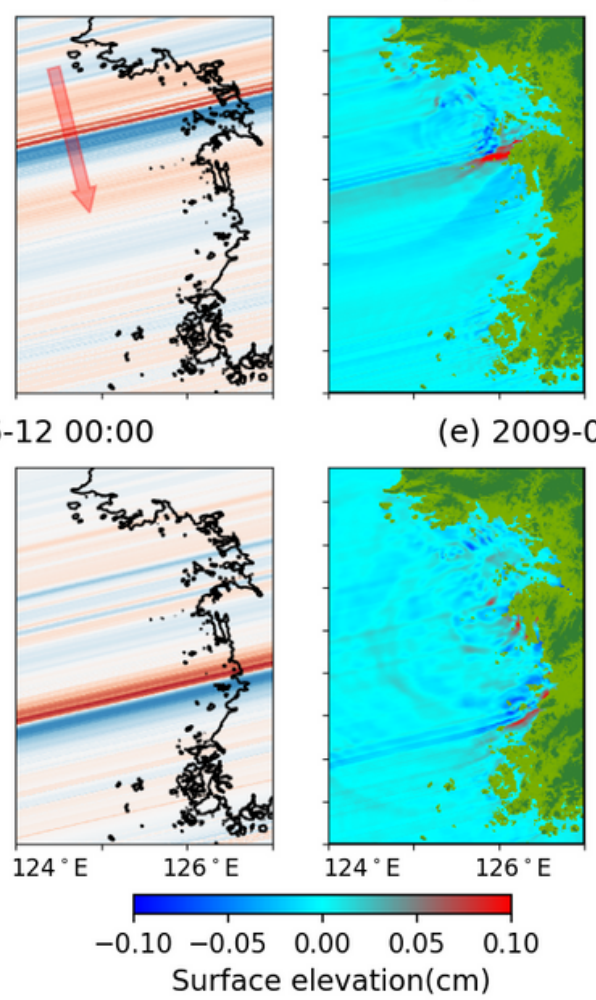

(e) 2009-06-12 01:00
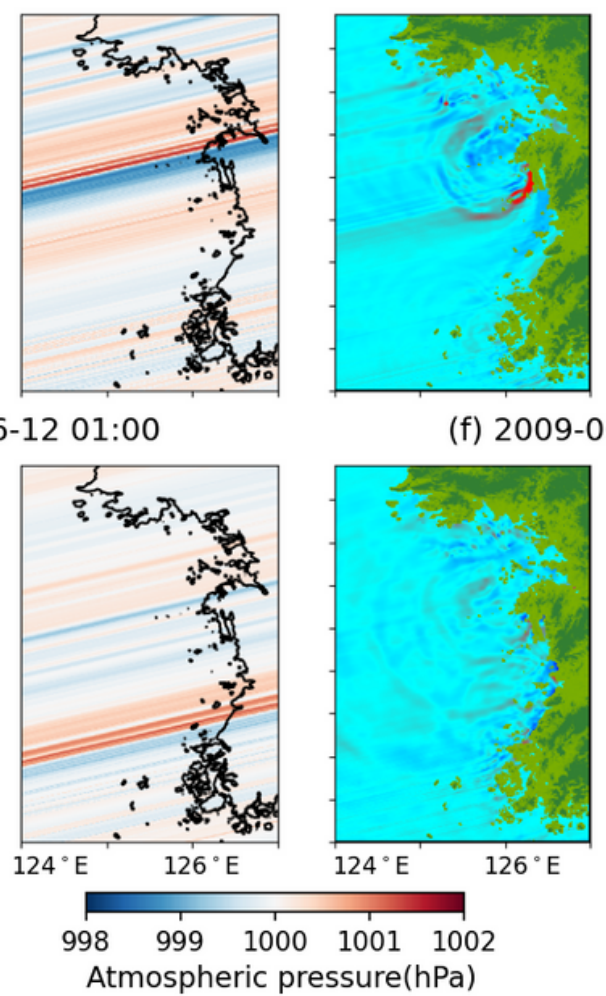

(c) 2009-06-11 23:00

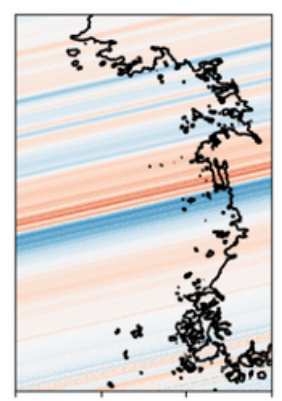

(f) 2009-06-12 02:00

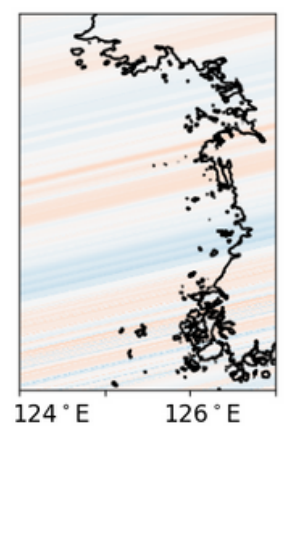

\section{Figure 9}

Numerical simulations of meteotsunami propagation from 11-12 June 2009. Color presents sea surface elevation $(\mathrm{cm})$ in the left panel and atmospheric pressure $(\mathrm{hPa})$ in the right panel each time. The moving direction and speed of the pressure jump are $280^{\circ}$ and $12 \mathrm{~m} / \mathrm{s}$, respectively. 